\title{
Design of Sewer Network for Kophrad Village, Virar-Vasai
}

\author{
Ajay Livingston ${ }^{1}$, Hemant Patel $^{2}$, Garrison Rumao ${ }^{3}$, Gaurav Vaghadia ${ }^{4}$, Dr. B. J. Godboley ${ }^{5}$ \\ ${ }^{1,2,3,4}$ (UG Students), ${ }^{5}$ Associate Professor, Department of Civil Engineering, St John College of Engineering \& \\ Management, Palghar
}

DOI: 10.46335/IJIES.2020.5.6.3

\begin{abstract}
The infrastructure of a city, mainly the water supply and sewerage system are vital for urbanization, wastewater generated from urban area is a result of domestic and industrial activities, and domestic wastewater contains organic and inorganic matter in suspended, colloidal and dissolved form. The municipal wastewater management is a critical issue in an urban environment. If the municipal wastewater is not properly collected, treated and disposed, the related effects pose serious threat to the environment. Many small cities do not have proper drainage system. As on date all the domestic waste water is either send in open drain or in open area around the houses. This is resulting in hygienic problems. This study aim at designing sewer system for a particular portion of the kophrad village.
\end{abstract}

\section{I- INTRODUCTION}

A sewerage system is composed of various sewer lines terminating at the junction of a large sewer line. The large sewer line also terminates at the junction of a still larger sewer line. Finally, the main sewer line terminates at the outfall. Thus, a sewerage system can be viewed as a set of sewer lines collecting discharges at their nodal points and emptying into another set of sewer lines.

In this paper attention is focused on the design of a sewer line and mapping of sewer network. GIS has been regarded and proven as an efficient and powerful tool in the wastewater industry. According to American Water Works Association, 90\% of water agencies are now partially using GIS to assist their daily operation. This open surface drain system has got many problems such as very easy for foreign matter to have entry in the open drains which hampers. The flow and creates stagnation of the sewage, creates odor nuisance, creates mosquito and files problems and deterioration of water quality.

A sewerage system is composed of various sewer lines terminating at the junction of a large sewer line. The large sewer line also terminates at the junction of a still larger sewer line. Finally, the main sewer line terminates at the outfall. Thus, a sewerage system can be viewed as a set of sewer lines collecting discharges at their nodal points and emptying into another set of sewer lines. In this paper attention is focused on the optimal design of a sewer line, which is a basic unit of a sewerage system. The problem consists of minimization of a nonlinear cost function subjected to nonlinear constraints. Camp (1946) was the first to emphasize the need for hydraulic design of sewers, which was neglected in the technical literature at that time as well as by the sewage works engineers. Since then a large number of research workers contributed to this subject. These approaches employed heuristic methodologies, which can be adapted on a microcomputer (Liebman 1967; Cook and Lockwood 1977; Mays 1978; Lorine 1982: Dasher and Davis 1986; Miles and Heaney 1988; Charalambous and Elimam 1990). Using dynamic programming, Argaman et al. (1973), Merritt and Bogan (1973), and Walsh and Brown (1973) affected the design. Using piecewise linearization, the problem was solved by linear programming by Dajani et al. (1972), Dajani and Hasit (1974), and Elimamet al. (1989). On the other hand, Jain (1987) and Tyagi (1989) used a sequential linear programming method to find the sewer diameters. Gupta et al. (1976) used Powell's method of conjugate 
directions to search the optima of the cost function. All these approaches use the Manning equation or Hazen Williams equation for resistance description. The Manning equation is applicable for a limited bandwidth, 0.004-0.04, of relative roughness (Christensen 1984). ASCE (1963) has disapproved the Manning equation and recommended the use of the Darcy-Weisbach equation for open-channel resistance.

\section{II- OBJECTIVES OF THE STUDY}

a Data collection required for designing of domestic sewage collection system.

b Design of sewage system.

The field data required for the design of the sewerage system such as details of exiting water supply, the ward wise and road wise population as per census, development plan etc. were collected from the kophrad (vasai-virar) Municipal council.

\section{III- POPULATION FORECASTING}

There are many methods for the population forecasting suitable for the town. From that the methods used is given below:

a. Arithmetical Increase Method: In this method, the average increase of population per decade is calculated from the past records and added to the present population to find out population in the next decades. This method gives low value and is suitable for well settled and established communities. Formulae of this method as below:

$$
\begin{aligned}
\mathrm{Pn}= & \mathrm{P} 1+\mathrm{n}^{* \mathrm{X}} \\
& \text { Where } \\
& \mathrm{Pn}=\text { Population in the nth Decades } \\
& \mathrm{P} 1=\text { Population in the latest Decades } \\
& \mathrm{n}=\text { No. of Decades } \\
& \mathrm{X}=\text { Avg. Arithmetical Increase }
\end{aligned}
$$

The number of people occupying the given area was obtained by official survey conducted by the government agencies at an interval of 10 years. Thus, obtained data was useful for forecasting the population for the village towards the end of the design period.

\begin{tabular}{|c|c|c|c|}
\hline Census & Population & Arithmetic increase & Growth rate \\
\hline 1988 & 11719 & & \\
\hline 1998 & 15238 & 3519 & 0.231 \\
\hline 2008 & 19789 & 4551 & 0.229 \\
\hline 2018 & 25700 & 5911 & 0.23 \\
\hline Total & 72446 & 13981 & 0.69 \\
\hline Average & 18111.5 & 4660.33 & 0.23 \\
\hline
\end{tabular}

\section{IV-DESIGN PARAMETERS}

a. Rate of Water Supply: Wastewater quantity may be assumed to be $80 \%$ of the quantity of water supply. The sewers should be designed for a minimum of $150 \mathrm{lpcd}$. Considering the waste from the houses apart from the area selected will also be drawn from these pipes. Therefore waste water quantity to be considered is $48 \mathrm{lpcd}$.

For rainfall flow rate:

$\mathrm{Q}=\mathrm{C}$ I A

Where,

$\mathrm{Q}=$ runoff in $\mathrm{m} 3 / \mathrm{hr}$

$\mathrm{C}=$ Dimensionless runoff coefficient $=1$

$\mathrm{I}=$ intensity of rainfall in $\mathrm{mm} / \mathrm{hr}$

$=20.83 \mathrm{~mm} / \mathrm{hr}$

$\mathrm{A}=$ Area of drainage in hectares

$=6$ hectares.

The value of $\mathrm{Q}$ is $34.44 \mathrm{lpcd}$.

Therefore total discharge is $82.44 \mathrm{lpcd}$

\section{b. Slope/Gradient}

Slope depends upon the topography of ground and levels. Slope is also another important parameter because the rate of flow is depends upon the amount of slope. velocity of the is also depends upon it along with the friction between fluid and pipe.

$\mathrm{M}=$ rise $/ \mathrm{run}=\mathrm{Y} 2-\mathrm{Y} 1 / \mathrm{X} 2-\mathrm{X} 1$

$=101 \cdot 7-101 \cdot 2 / 10-5 \&$ so on

\section{c. Peak Factor}

The peak factor or the ratio of maximum to average flow depends upon contributory population and the following values are recommended. These peak factors will be applied to the projected population for the design year considering an average wastewater flow based on allocation

\begin{tabular}{|l|l|l|}
\hline Sr No & Population & Peak factor \\
\hline 1 & up to 20000 & 3.5 \\
\hline 2 & 20000 to 50000 & 2.5 \\
\hline 3 & 50000 to 75000 & 2.25 \\
\hline 4 & above 75000 & 2 \\
\hline
\end{tabular}

d. Velocity: The sanitary sewer is designed to obtain adequate scouring velocities at the average or at least at the maximum flow at the beginning of the design period for a given flow and slope. Velocity 
International Journal of Innovations in Engineering and Science, Vol 5, No.6, 2020 $w w w . i j i e s . n e t$

is little influenced by pipe diameter. The recommended slope for minimum velocity is 0.75 metre/sec. and maximum velocity is 3.00 meter $/ \mathrm{sec}$.Here the sewer velocity is $2.1 \mathrm{~m} / \mathrm{sec}$.

e. Pipe Size: The pipe size should be decided on the basis of ultimate design peak flow and the permissible depth of flow. The minimum diameter of public sewer may be $150 \mathrm{~mm}$. In hilly areas, where extreme slope are prevalent, the size of sewer may be $100 \mathrm{~mm}$. The size of the pipe is calculated by the formula square root of flow rate times 4 divided by 3.14 times velocity.

$$
\begin{aligned}
& \begin{array}{l}
\text { size of } \\
\text { pipe }
\end{array}=\sqrt{ }\left(\begin{array}{lll}
\text { flow } & & \\
\text { rate } & x & 4 \\
\hline 3.14 & \mathrm{x} & \text { velocity }
\end{array}\right)
\end{aligned}
$$

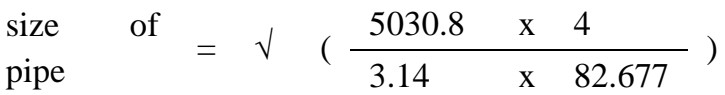

$$
\begin{aligned}
& =8.804219 \quad \text { inches } \\
& =\quad 223.62 \mathrm{~mm}
\end{aligned}
$$

f. Depth of Cover: $01 \mathrm{~m}$ cover on pipeline is normally sufficient to protect the pipe lines from external damage.

g. Manholes: Manholes are interconnecting between two or more sewers and to provide entry of sewers. Manholes are used to building connections and junction chambers.

\section{V- PLACING OF SEWERAGE SYSTEM}

a Survey: The survey of the desired area is done to find the reduced level of the area for the purpose of finding the slope, in order to design the position of the sewer pipe. The survey is done using a total station i.e. by total station method. The layout of the line diagram is given below:

\section{VI-RESULTS}

\begin{tabular}{|c|c|c|c|c|c|}
\hline $\begin{array}{c}\text { Pipe } \\
\text { no }\end{array}$ & $\begin{array}{c}\mathbf{Q} \\
\mathbf{( l p s )}\end{array}$ & $\begin{array}{c}\mathbf{Q} \\
\left.\mathbf{( \mathbf { m } ^ { 3 }} \mathbf{/ s}\right)\end{array}$ & $\begin{array}{c}\text { LENGT } \\
\mathbf{H} \mathbf{( m )}\end{array}$ & $\begin{array}{c}\text { DIAME } \\
\mathbf{T E R} \\
\mathbf{( m )}\end{array}$ & $\begin{array}{c}\text { HEADLO } \\
\mathbf{S S} \\
\mathbf{( m )}\end{array}$ \\
\hline 1 & 800 & 0.80 & 88.74 & 0.3 & 0.361 \\
\hline 2 & 42.08 & 0.042 & 64.39 & 0.3 & 0.069 \\
\hline 3 & 54.96 & 0.054 & 88.71 & 0.3 & 0.238 \\
\hline 4 & 66.58 & 0.066 & 97.62 & 0.3 & 0.026 \\
\hline 5 & 91.25 & 0.091 & 62.82 & 0.3 & 0.487 \\
\hline
\end{tabular}

\begin{tabular}{|c|c|c|c|c|c|}
\hline 6 & 40.65 & 0.040 & 83.86 & 0.3 & 0.048 \\
\hline 7 & 14.65 & 0.0146 & 30.74 & 0.3 & 0.009 \\
\hline 8 & 59.25 & 0.059 & 9.13 & 0.3 & 0.142 \\
\hline 9 & 60.25 & 0.060 & 136.4 & 0.3 & 0.177 \\
\hline 10 & 139.9 & 0.139 & 96.49 & 0.3 & 0.743 \\
\hline 11 & 14.90 & 0.0149 & 94.16 & 0.3 & 0.010 \\
\hline 12 & 200.6 & 0.2006 & 38.42 & 0.3 & 0.752 \\
\hline
\end{tabular}

\begin{tabular}{|c|c|c|c|}
\hline $\begin{array}{c}\text { NOD } \\
\text { E }\end{array}$ & HGL (m) & $\begin{array}{c}\text { ELEVATIO } \\
\text { N (m) }\end{array}$ & $\begin{array}{c}\text { PRESSURE } \\
\text { HEAD (m) }\end{array}$ \\
\hline 1 & 10 & 9 & 1 \\
\hline 2 & 10 & 9 & 1 \\
\hline 3 & 10 & 9 & 1 \\
\hline 4 & 10 & 9 & 1 \\
\hline 5 & 10 & 8 & 2 \\
\hline 6 & 10 & 8 & 2 \\
\hline 7 & 10 & 8 & 2 \\
\hline 8 & 10 & 8 & 2 \\
\hline 9 & 10 & 8 & 2 \\
\hline 10 & 10 & 8 & 2 \\
\hline 11 & 10 & 8 & 2 \\
\hline 12 & 10 & 7 & 3 \\
\hline
\end{tabular}

\section{VI-CONCLUSION}

The available population data of kophrad village from year 1988 to 2018, the population growth rate is 0.23 . Do not have proper drainage system, so underground sewage system is required for evading the problem of water percolation.

Planning of a proper sewage system will solve problems of pipe blockage, disease etc.

\section{REFERENCES}

[1] Argaman, Y., Shamir, U., and Spivak, E. (1973). “Design of optimal sewerage system." J. Envir. Engrg. Div., ASCE, 99(5), 703-716.

[2] ASCE Task Force on Friction Factors in Open Channels. (1963). "Friction factors in open channels. " J. Hydr. Div., ASCE, 89(2), 97-143.

[3] Binder, R. C. (1975). Fluid mechanics, 5th Ed., Prentice-Hall of India, New Delhi.

[4] Camp, T. R. (1946). "Design of sewers to facilitate flow. ' Sewage Works J., 18(1), 3-16. 
[5] Charalambous, C., and Elimam, A. A. (1990). "Heuristic design of sewer networks." J. Envir. Engrg., ASCE, 116(6), 1181-1199.

[6] Christensen, B. A. (1984). "Discussion of 'Flow velocities in pipelines, 'by Richard R. Pomeroy. ' J. Hydr. Engrg., ASCE, 110(10), 1510-1512.

[7] Cook, L. A., and Lockwood, B. (1977). "The investigation of sewer network by computer. ' J. Inst. of Civ. Engrs., Part 2, 63(2), 481-494.

[8] Dajani, J. S., Gemmel, R. S., and Morlok, E. K. (1972). "Optimal design of urban wastewater collection networks." J. Sanit. Engrg. Div., ASCE, 98(6), 853-867.

[9] Dajani, J. S., and Hasit, Y. (1974). " Capital cost minimization of drainage networks." J. Envir. Engrg. Div., ASCE, 100(2), 325-337.

[10] Dasher, D. P., and Davis, P. K. (1986). "Designing sanitary sewers with microcomputers." J. Envir. Engrg., ASCE, 112(6), 993-1007.

[11] Elimam, A. A., Charalombus, C., and Ghobrial, F. H. (1989). "Optimal design of large sewer networks." J. Envir. Engrg., ASCE, 115(6), 1171-1189.

[12] Gupta, J. M., Agarwal, S. K., and Khanna, P. (1976). "Optimal design of wastewater collection system." J. Envir. Engrg. Div., ASCE, 102(5), 1029-1041.

[13] Jain, R. K. (1987). "Optimal design of a sewer line." ME dissertation, University of Roorkee, Roorkee, Uttaranchal, India.

[14] Liebman, J. C. (1967). "A heuristic aid for the design of sewer networks." J. Sanit. Engrg. Div., ASCE, 93(4), 81-90.

[15] Liou, C. P. (1998). "Limitations and proper use of the Hazen-Williams equation." J. Hydr. Engrg., ASCE, 124(9), 951-954.

[16] Lorine, J. M. (1982). “Sanitary sewer design." Civ. Engrg., ASCE, 52(6), 66-67.

[17] Manual on sewerage and sewage treatment. (1984). Central Public Health and Envir. Engrg. Org., Ministry of Works and Housing, New Delhi.

[18] Mays, L. W. (1978). "Sewer network scheme for digital computations.” J. Envir. Engrg. Div., ASCE, 104(3), 535-539.

[19] Merritt, L. B., and Bogan, R. H. (1973). "Computerbased optimal design of sewer systems.' J. Envir. Engrg. Div., ASCE, 99(1), 35-53.

[20] Miles, S. W., and Heaney, J. P. (1988). "Better than 'optimal' method for designing drainage systems., J. Water Resour. Plng. and Mgmt., ASCE, 114(5), 477-499.

[21] Nalluri, C., and Dabrowski, W. (1994). "Need for new standards to prevent deposition in wastewater sewer.' J. Envir. Engrg., ASCE, 120(5), 1032-1043.

[22] Swamee, P. K. (1994). "Normal depth equations for irrigation canals.'J. Irrig. and Drain. Engrg., ASCE, 120(5), 942-948.

[23] Swamee, P. K., Bhargava, R., and Sharma, A. K.
(1987). “Non-circular sewer design." J. Envir. Engrg., ASCE, 113(4), 824-833.

[24] Swamee, P. K., and Jain, A. K. (1976). "Explicit equations for pipe flow problems." J. Hydr. Div., ASCE, 102(5), 657-664.

[25] Swamee, P. K., Mishra, G. C., and Chahar, B. R. (2000). "Minimum cost design of lined canal sections." J. Water Resour. Mgmt., Dordrecht, The Netherlands, 14(1), 1-12.

[26] Tyagi, A. (1989). “'Optimal sewer line design.” ME dissertation, University of Roorkee, Roorkee, Uttaranchal, India.

[27] Walsh, S., and Brown, L. C. (1973). "Least cost method for sewer designs." J. Envir. Engrg. Div., ASCE, 99(3), 333-345. 